\title{
PENGATURAN GIZI SEIMBANG BAGI PENDERITA HIPERTENSI
}

Oleh: Cerika Rismayanthi

Dosen Jurusan Pendidikan Kesehatan dan Rekreasi FIK UNY

\section{Abstrak}

Saat ini penyakit degeneratif dan kardiovaskuler sudah merupakan salah satu masalah kesehatan masyarakat di Indonesia. Hasil Survei Kesehatan Rumah Tangga (SKRT) tahun 1972, 1986 dan 1992 menunjukkan peningkatan prevalensi penyakit kardiovaskuler yang menyolok sebagai penyebab kematian dan sejak tahun 1993 diduga sebagai penyebab kematian nomor satu. Penyakit tersebut timbul karena berbagai faktor risiko seperti kebiasaan merokok, hipertensi, disiplidemia, diabetes mellitus, obesitas, usia lanjut dan riwayat keluarga. Dari faktor risiko diatas yang sangat erat kaitannya dengan gizi adalah hipertensi, obesitas, disiplidemia dan diabetes mellitus.

Hipertensi atau yang lebih dikenal dengan penyakit darah tinggi adalah suatu keadaan dimana seseorang mengalami peningkatan tekanan darah diatas normal yang mengakibatkan peningkatan angka kesakitan (morbiditas) dan angka kematian (mortalitas). Penulisan tekanan darah seperti $110 / 70 \mathrm{mmHg}$ adalah didasarkan pada dua fase dalam setiap denyut jantung. Nilai yang lebih tinggi (sistolik) menunjukkan fase darah yang sedang dipompa oleh jantung, nilai yang lebih rendah (diastolik) menunjukkan fase darah kembali ke dalam jantung.

Masalah gizi klinis merupakan masalah gizi yang erat hubungannya dengan penyakit dan penanganannya memcrlukan tindakan yang komprehensif. Sehingga hipertensi yang merupakan salah satu faktor risiko terjadinya penyakit kardiovaskuler, perlu dicegah dan

Pengaturan Gizi Seimbang Bagi Penderita Hipertensi (Cerika Rismayanthi) 
diobati dengan merubah pola makan menjadi pola makan sehat yang berpedoman pada aneka ragam makanan yang memenuhi gizi seimbang.

Kata Kunci: Hipertensi, Gizi

\section{HUBUNGAN GIZI DAN HIPERTENSI}

Istilah hipertensi berasal dari bahasa Inggris "hypertension". Kata "hypertension" sendiri berasal dari bahasa Latin, yaitu "hyper" dan "tension". "hyper" berarti tekanan atau tegangan. Akhirnya hypertension menjadi istilah kedokteran yang cukup populer untuk menyebut penyakit tekanan darah tinggi. Selain itu, dalam bahasa Inggris digunakan juga istilah "high blood pressure" yang berarti tekanan darah tinggi (http://www.pikiran-rakyat.com). Menurut www.kompas.com Hipertensi berdasarkan penyebabnya dapat diklasifikasikan sebagai berikut:

1. Hipertensi primer, yaitu hipertensi yang tidak diketahui penyebabnya.

2. Hipertensi sekunder, yaitu hipertensi yang disebabkan oleh penyakit, obat-obatan, maupun kehamilan.

Sedangkan klasifikasi hipertensi menurut WHO berdasarkan tekanan diastolik, yaitu:

1. Hipertensi derajat I, yaitu jika tekanan diastoliknya 95-109 $\mathrm{mmHg}$.

2. Hipertensi derajat II, yaitu jika tekanan diastoliknya 110-119 $\mathrm{mmHg}$.

3. Hipertensi derajat III, yaitu jika tekanan diastoliknya lebih dari $120 \mathrm{mmHg}$.

MEDI KORA Vol. V, No 1, April 2009: 34-54 
Hipertensi diduga dapat berkembang menjadi masalah kesehatan yang lebih serius dan bahkan dapat menyebabkan kematian (www.kompas.com). Seringkali hipertensi disebut sebagai silent killer karena dua hal, yaitu:

1. Hipertensi sulit disadari oleh seseorang karena hipertensi tidak memiliki gejala khusus. Gejala ringan seperti pusing, gelisah, mimisan, dan sakit kepala biasanya jarang berhubungan langsung dengan hipertensi. Hipertensi dapat diketahui dengan mengukur tekanan darah secara teratur.

2. Penderita hipertensi, apabila tidak ditangani dengan baik, akan mempunyai risiko besar untuk meninggal karena komplikasi kardiovaskular seperti stroke, serangan jantung, gagal jantung, dan gagal ginjal.

Hipertensi adalah suatu keadaan dimana tekanan darah meningkat melebihi batas normal. Batas tekanan darah normal bervariasi sesuai dengan usia. Berbagai faktor dapat memicu terjadinya hipertensi, walaupun sebagian besar (90\%) penyebab hipertensi tidak diketahui (hipertensi essential). Penyebab tekanan darah meningkat adalah peningkatan kecepatan denyut jantung, peningkatan resistensi (tahanan) dari pembuluh darah tepi dan peningkatan volume aliran darah. Faktor gizi yang sangat berhubungan dengan terjadinya hipertensi melalui beberapa mekanisme. Aterosklerosis merupakan penyebab utama terjadinya hipertensi yang berhubungan dengan diet seseorang, walaupun 
faktor usia juga berperan, karena pada usia lanjut (usila) pembuluh darah cenderung menjadi kaku dan elastisitasnya berkurang.

Pembuluh yang mengalami sklerosis (aterosklerosis), resistensi dinding pembuluh darah tersebut akan meningkat. Hal ini akan memicu jantung untuk meningkatkan denyutnya agar aliran darah dapat mencapai seluruh bagian tubuh. Menurut Maria C. Linder, Ph.D dari California State University, Fullerton, CA, masih menjadi perdebatan kontroversi tentang pengaruh faktor diet dan cara hidup terhadap terjadinya aterosklerosis. Namun dari beberapa kecenderungan menyatakan bahwa: 1) terjadinya plak (plaque) aterosklerosis merupakan suatu respon dari cedera pada dinding arteri terhadap kerusakan yang dibentuk oleh lapisan epitel; 2) serat makanan, $\mathrm{Mg}$ dan beberapa mikronutrien seperti $\mathrm{Cr}$, $\mathrm{Cu}$ mungkin penting dalam pencegahan jangka panjang atau memperlambat aterosklerosis. Selain itu konsumsi tinggi kolesterol dan lemak yang memicu terjadinya aterosklerosis. Aterosklerosis terjadi bila sebagian besar permukaan bagian dalam arteri besar membentuk plaque. Ada tiga macam plaque, yaitu:

1. Raise Plaque

Terdiri dari peninggian sel-sel urat daging licin, serat, lipid dan puing-puing (jaringan nekrotik adalah suatu penebalan lapisan medial), kalsifikasi dan hemoragi dari dinding arteri. Plaque tersebut menonjol ke arah lumen dan menyebabkan pengurangan aliran darah dan elastisitas pembuluh darah. Ini akan menyebabkan terbentuknya trombus yang oklusif

MEDIKORA Vol. V, No 1, April 2009: 34-54 
(pembekuan) dan dapat menyebabkan infark miokardium dan stroke.

2. Plak yang disebut Fatty Streaks

Terdiri dari proferasi sel-sel urat daging licin bersama dengan berbagai lipid intra dan ekstra sekuler.

3. Fibrosis Plaque

Serat-serat tenunan pengikat membentuk semacam tutup / topi diatas lipid ekstraselluler bagian dalam dan sisa-sisa seluler membentuk pinggiran yang mengganggu lumen.

Faktor-faktor penyebab cenderungnya dinding pembuluh darah membentuk plak antara lain: cedera mekanis, panas/dingin, zat-zat kimia, virus, homosistein dan kolesterol. Hasil pengamatan epidemiologi yang membandingkan populasi atau sub populasi di beberapa negara, menunjukkan bahwa banyak faktor cara hidup dan makanan yang menyebabkan risiko menjadi lebih besar untuk menderita penyakit kardiovaskuler. Berikut ini memperlihatkan faktor risiko penyebab aterosklerosis, yaitu:

\section{Primer :}

- Merokok ( ${ }^{3} 1$ pak sehari)

- Tekanan darah (diastolik_ 90 m Hg, sistolik > 105 mm Hg)

- Peningkatan kolesterol plasma (> 240-250 mg/dl)

\section{Sekunder :}

- Peningkatan trigliserida plasma

- Obesitas

- Diabetes 
- Stress kronis

- Pil KB

- Vasektomi

Sumber: Informasi dari Naito (1980) dan Connor (1980)

Merokok, tekanan darah tinggi dan peningkatan kadar kolesterol plasma/serum adalah faktor risiko utama terjadinya asteroklerosis, sedangkan penyebab sekunder adalah stress, kurang gerak, peningkatan trigliserida plasma. Rasio kolesterol HDL: LDL berbanding terbalik dengan terjadinya asteroklerosis dan ini lebih berarti daripada hubungan dengan total kolesterol serum LDL yang berlebihan memicu terjadinya asteroklerosis pada dinding pembuluh darah. Selain konsumsi lemak yang berlebih, kekurangan konsumsi zat gizi mikro (vitamin dan mineral) sering dihubungkan pula dengan terjadinya ateroklerosis, antara vitamin C, vitamin E dan B6 yang meningkatkan kadar homosistein. Tingginya konsumsi vitamin D merupakan faktor terjadinya asteroklerosis dimana terjadi deposit kalsium yang menyebabkan rusaknya jaringan elastis sel dinding pembuluh darah.

\section{GIZI SEIMBANG}

Menurut Djoko Pekik (2006: 2) Istilah gizi berasal dari bahasa Arab "Giza" yang berarti zat makanan, dalam bahasa Inggris dikenal dengan istilah nutrition yang berarti bahan makanan atau zat gizi atau sering diartikan sebagai ilmu gizi. Dapat juga diartikan sari makanan yang bermanfaat untuk kesehatan. Manusia dalam

MEDIKORA Vol. V, No 1, April 2009: 34-54 
proses pertumbuhan dan perkembangannya, dimulai dari saat pembuahan, berlangsung sepanjang masa hidupnya hingga dewasa sampai masa tua, memerlukan zat gizi yang terkandung dalam makanan. Jadi manusia mendapat zat gizi atau nutrien dalam bentuk makanan yang berasal dari hewan (hewani) dan tumbuhtumbuhan (nabati).

Lebih luas gizi diartikan sebagai suatu proses organisme menggunakan makanan yang dikonsumsi secara normal melalui proses pencernaan, penyerapan, transportasi, penyimpanan, metabolisme dan pengeluaran zat gizi untuk mempertahankan kehidupan, pertumbuhan dan fungsi normal organ tubuh serta untuk menghasilkan tenaga. Bogert (1973) mendefinisikan ilmu gizi sebagai ilmu yang mempelajari cara memberi makan tubuh yang layak atau pantas.

Zat gizi tersebut adalah karbohidrat, protein dan lemak yang disebut sebagai zat gizi makro serta vitamin dan mineral yang disebut dengan zat gizi mikro. Selain itu, untuk memperlancar proses metabolisme dalam tubuh diperlukan air dan serat. Tubuh manusia membutuhkan aneka ragam makanan untuk memenuhi semua zat gizi tersebut. Kekurangan atau kelebihan salah satu unsur zat gizi akan menyebabkan kelainan atau penyakit. Oleh karena itu, perlu diterapkan kebiasaan makanan yang seimbang sejak usia dini dengan jumlah yang sesuai kebutuhan masingmasing individu agar tercapai kondisi kesehatan yang prima.

Pengaturan Gizi Seimbang Bagi Penderita Hipertensi (Cerika Rismayanthi) 
Hidangan "gizi seimbang" adalah makanan yang mengandung zat tenaga, zat pembangun dan zat pengatur. Zat tenaga atau kalori diperlukan untuk melakukan aktivitas seharihari yang sebagian besar dibutuhkan dari bahan makanan sumber karbohidrat dan lemak serta sedikit protein. Zat pembangun atau protein ini penting untuk pertumbuhan dan mengganti sel-sel rusak yang didapatkan dari bahan makanan hewani atau tumbuhtumbuhan (nabati).

Bahan makanan sumber zat tenaga dari karbohidrat, antara lain: beras, jagung, gandum, ubi jalar, kentang, sagu, roti, mie, pasta makaroni dan tepung-tepungan disamping gula murni, baik sukrosa, glukosa atau laktosa. Sedangkan bahan makanan sumber zat tenaga dari lemak antara lain: lemak hewani, minyak, santan, margarine dan mentega. Bahan makanan sumber zat pembangun yang berasal dari hewani antara lain: daging, ikan, ayam, telur, udang, kerang sari serta turunannya (seperti keju, yoghurt, dll). Sumber zat pengatur adalah semua sayur-sayuran dan buahbuahan yang mengandung berbagai vitamin dan mineral yang berperan untuk proses metabolisme atau bekerjanya fungsi organ tubuh. Selain itu, air juga diperlukan untuk proses metabolisme. Sedangkan serat juga dibutuhkan oleh tubuh terutama untuk memberikan isi perut (bulky) dan membantu memperlancar proses buang air besar. Selain itu serat juga mempengaruhi penyerapan zat gizi dalam usus. Disamping "4 Sehat 5 Sempurna", pola makan

MEDIKORA Vol. V, No 1, April 2009: 34-54 
yang mengikuti “13 Pesan Dasar Gizi Seimbang” sangat dianjurkan untuk mendapatkan kecukupan zat gizi (Vitahealth, 2006).

1. Makanlah aneka ragam makanan Makan yang beraneka ragam akan saling melengkapi kekurangan zat 'gizi dari berbagai makanan, yang menjamin terpenuhinya kecukupan sumber zat tenaga, zat pembangun dan zat pengatur.

2. Makanlah makanan untuk memenuhi kecukupan energi Setiap orang dianjurkan makan makanan yang cukup mengandung energi agar dapat melakukan aktivitas sehari-hari.

3. Makanlah makanan sumber karbohidrat, setengah dari kebutuhan energi

Dianjurkan menggunakan sumber karbohidrat kompleks (padipadian, umbi-umbian dan tepung-tepungan) daripada karbohidrat murni (gula).

4. Batasi konsumsi lemak dan minyak sampai seperempat dari kecukupan energi

Lemak dan minyak berguna untuk meningkatkan jumlah energi, membantu penyerapan vitamin A, D, E, dan $\mathrm{K}$ serta menambah lezatnya hidangan. Dianjurkan menggunakan lemak dan minyak nabati, karena mudah dicerna oleh tubuh.

5. Gunakan garam beryodium

Garam beryodium adalah garam natrium yang diperkaya dengan kalium yodida, sebanyak 30-80 ppm. Setiap keluarga dianjurkan untuk menggunakan garam beryodium untuk 
memasak/mengolah makanan agar tidak terjadi Gangguan Akibat Kurang Yodium (GAKY).

6. Makanlah makanan sumber zat besi

Zat besi/Fe adalah salah satu unsur penting untuk membentuk hemoglobin $(\mathrm{Hb})$ atau sel darah merah. Kurang zat besi dapat menyebabkan anemia. Sumber zat besi yang baik berasal dari makanan hewani (heme-iron) dibandingkan dari makanan nabati (nonheme-iron).

7. Berikan ASI saja pada bayi sampai umur 4 bulan

ASI adalah makanan terbaik untuk bayi, karena kandungan zat gizinya lengkap, mengandung zat kekebalan dan memberikan ASI akan mempererat jalinan kasih sayang ibu dan bayinya.

8. Biasakan makan pagi

Makan pagi atau sarapan sangat bermanfaat karena memelihara ketahanan fisik, mempertahankan daya tahan saat bekerja dan meningkatkan produktivitas kerja.

9. Minumlah air bersih, aman yang cukup jumlahnya Air minum harus bersih dan bebas kuman dengan cara mendidihkan atau diproses dengan alat (air minum dalam kemasan). Fungsi air minum dalah tubuh adalah untuk melancarkan transportasi zat gizi, mengatur keseimbangan cairan dan garam mineral, mengatur suhu tubuh dan mengeluarkan sisa metabolisme. Dianjurkan minum sekurangkurangnya 2 liter atau 8 gelas sehari untuk mencegah dehidrasi dan menurunkan risiko penyakit ginjal.

MEDIKORA Vol. V, No 1, April 2009: 34-54 
10. Lakukan kegiatan fisik dan olahraga secara teratur Kegiatan fisik dan olahraga (setiap hari jalan kaki) sangat dianjurkan untuk meningkatkan kebugaran, mencegah kelebihan berat badan, meningkatkan fungsi jantung, paru dan otot serta memperlambat proses menua.

11. Hindari minum minuman beralkohol

Alcohol hanya mengandung energi, tanpa mengandung zat gizi lain. Kebiasaan minum alcohol dapat mengakibatkan: kurang gizi, penyakit gangguan hati, kerusakan saraf otak dan jaringan serta menyebabkan kecanduan.

12. Makanlah makanan yang aman bagi kesehatan

Makanan yang aman adalah makanan bebas dari kuma dan bahan nimia berbahaya, serta tidak bertentangan dengan keyakinan masyarakat.

13. Bacalah label pada makanan yang dikemas

Label pada makanan yang dikemas adalah keterangan tentang isi, jenis dan ukuran bahan-bahan yang digunakan, susunan zat gizi, tanggal kadaluwarsa dan keterangan penting lain. Hal tersebut sangat membantu konsumen pada saat memilih dan membeli makanan tersebut, sesuai kebutuhan gizi dan kondisi kesehatan konsumen.

Kebutuhan gizi setiap individu berbeda, dipengaruhi oleh faktorfaktor dibawah ini:

1. Umur: masa pertumbuhan dari janin, bayi, balita, usia remaja sampai dewasa muda membutuhkan zat gizi cukup. 
Kekurangan zat gizi pada masa tersebut akan mempengaruhi proses tumbuh kembang. Contoh: kurang yodium pada ibu hamil menyebabkan anak kretin.

2. Jenis Kelamin: pada umumnya laki-laki memerlukan zat gizi lebih dibandingkan wanita karena luas permukaan tubuh maupun otot pada laki-laki lebih besar daripada wanita. Namun kebutuhan Fe pada wanita cenderung lebih tinggi karena wanita mengalami menstruasi.

3. Aktivitas: kegiatan atau pekerjaan sehari-hari yang lebih aktif baik fisik maupun mental memerlukan energi/kalori yang lebih banyak.

4. Wanita hamil dan orang yang baru sembuh dari sakit umumnya memerlukan zat gizi yang lebih banyak. Namun pada penderita penyakit-penyakit tertentut seperti jantung, diabetes mellitus, hipertensi dan penyakit degeneratif lain memerlukan diet khusus dimana ada unsur zat gizi dengan jumlah tertentu yang harus dibatasi.

5. Lingkungan yang dingin membutuhkan kalori dan protein yang lebih. Demikian pula orang yang berada di lingkungan bahan nuklir harus mendapatkan suplemen khusus (vitamin dan mineral) untuk melindungi sel-sel tambahan dari efek radiasi.

\section{POLA MAKAN SEHAT UNTUK MENCEGAH HIPERTENSI}

Sebagaimana dijelaskan bahwa faktor penyebab utama terjadinya hipertensi adalah asteroklerosis yang didasari dengan

MEDI KORA Vol. V, No 1, April 2009: 34-54 
konsumsi lemak berlebih, oleh karena untuk mencegah timbulnya hipertensi adalah mengurangi konsumsi lemak yang berlebih disamping pemberian obat-obatan bilamana diperlukan. Pembatasan konsumsi lemak sebaiknya dimulai sejak dini sebelum hipertensi muncul, terutama pada orang-orang yang mempunyai riwayat keturunan hipertensi dan pada orang menjelang usia lanjut. Scbaiknya mulai umur 40 tahun pada wanita agar lebih berhati-hati dalam mengkonsumsi lemak pada usia mendekati menopause (http://hypertension.medicweb.org). Prinsip utama dalam melakukan pola makan sehat adalah "gizi seimbang", dimana mengkonsumsi beragam makanan yang seimbang dari "kuantitas" dan "kualitas" yang terdiri dari:

1. Sumber karbohidrat : biji-bijian.

2. Sumber protein hewani : ikan, unggas, daging putih, putih telur, susu rendah/bebas lemak.

3. Sumber protein nabati : kacang-kacangan dan polong-polongan serta hasil olahannya.

4. Sumber vitamin dan mineral : sayur dan buah-buahan segar.

\section{CAPAI DAN PERTAHANKAN BERAT BADAN IDEAL}

Pola makan sehat bertujuan untuk menurunkan dan mempertahankan berat badan ideal, sehingga dianjurkan untuk menyeimbangkan asupan kalori dengan kebutuhan energi total dengan membatasi konsumsi makanan yang mengandung kalori tinggi dan atau makanan yang kandungan gula dan lemaknya 
tinggi. Disamping itu, agar melakukan aktifitas fisik yang cukup untuk mencapai kebugaran jasmani yang baik dengan menyeimbangkan pengeluaran dan pemasukan energi/kalori. Untuk nłenurunkan berat badan, penggunaan energi harus melebihi asupannya (K, Darwin dan Muhilal:1991).

Secara umum untuk menurunkan berat badan dapat dicapai dengan menurunkan asupan total kalori. Dianjurkan untuk menurunkan berat badan 0,5-1 kg per minggu. Sehingga kebutuhan kalori harus dikurangi 500-1000 KKal/hari. Dianjurkan untuk meningkatkan penggunaan sayuran, buah-buahan, kacangkacangan dan produk biji-bijian serta mengurangi bahan makanan hewani (daging merah), lemak atau minyak jenuh (mentega atau santan), karbohidrat murni (gula, tepung-tepungan) dan yang mengandung alkohol. Dalam menjalankan diet rendah kalori, agar berhati-hati terjadinya kekurangan zat gizi mikro (vitamin dan mineral).

Perhitungan energi sangat penting pada diet untuk mempertahankan atau menurunkan BB mencapai ideal. Diet tinggi lemak dapat menyebabkan kenaikan BB dalam waktu cepat. Namun harus diperhitungkan pula asupan dari seluruh total energi per hari terutama dari sumber makro nutrisi, yaitu: karbohidrat, protein dan lemak. 1 gram lemak setara dengan $9 \mathrm{kkal}, 1$ gram karbohidrat dan protein setara dengan 4 kkal sedangkan 1 gram alcohol setara dengan $7 \mathrm{kkal}$. Oleh karena itu, komposisi makronutrien yang dianjurkan adalah mengurangi bahan makanan

MEDI KORA Vol. V, No 1, April 2009: 34-54 
terutama dari sumber-sumber lemak dan protein, terutama bagi usia dewasa sampai usia lanjut (> 40 tahun).

\section{CAPAI DAN PERTAHANKAN KADAR KOLESTEROL}

Lemak jenuh adalah penentuan utama peningkatan kadar kolesterol, sehingga dianjurkan untuk menurunkan asupan lemak jenuh $<10 \%$ asupan total energi dengan membatasi asupan makanan kaya asam lemak jenuh (susu tinggi lemak dan produknya, daging berlemak serta minyak kelapa). Pada orang dengan kadar kolesterol LDL tinggi atau dengan penyakit kardiovaskuler, lemak jenuhnya harus lebih rendah $(<7 \%$ total energi).

Asam lemak trans diet dapat meningkatkan kolesterol LDL dan menurunan colesterol HDL. Asam lemak ini terdapat pada produk makanan jadi yang mengandung minyak tumbuhan yang terhidrogenasi sebagian seperti kue kering, kraker, makanan yang dipanggang dan digoreng. Minyak yang digunakan pada makanan yang digoreng di kebanyakan restoran kemungkinan mengandung asam lemak trans yang tinggi. Untuk menjaga agar tidak terjadi peningkatan kadar kolesterol, dianjurkan untuk mengkonsumsi total sumber asam lemak ( $<10 \%$ kebutuhan energi). Disamping itu juga harus menurunkan konsumsi bahan makanan tinggi kolesterol, walaupun bahan makanan tersebut rendah sumber asam lemak jenuh. Colesterol dalam makanan dapat juga meningkatkan kadar kolesterol LDL, walaupun tidak sebanyak 
lemak jenuh. Kebanyakan makanan tinggi lemak jenuh juga merupakan sumber kolesterol, sehingga mengurangi komsumsi makanan ini akan memberikan keuntungan lebih yaitu pembatasart asupan kolesterol. Makanan kaya colesterol tetapi rendah kadar asam lemak jenuh (kuning telur) serta kacangkacangan dengan kadar lebih rendah sehingga efeknya lebh kecil terhadap kolesterol LDL (http://www.pikiran-rakyat.com).

\section{KONSUMSI TARGET KADAR KOLESTEROL YANG DICAPAI}

Menurut Vita Health, 2006, sebagai kompensasi pengurangan sumber asam lemak jenuh dan trans dibutuhkan sumber makanan lain dari karbohidrat dan lemak tak jenuh. Dapat juga ditambahkan beberapa jenis serat yang larut seperti havermouth untuk mengurangi kolesterol LDL. Dari berbagai penelitian dapat disimpulkan bahwa peningkatan penggunaan serat untuk setiap gram dapat menurunkan kolesterol LDL rata-rata 2,2 $\mathrm{mg} / \mathrm{dl}$. Sehingga dianjurkan diet tinggi serat yang diperoleh dari sumber karbohidrat seperti nasi, jagung, ubi, gandum, kentang, talas, oat. Makanan yang diperkaya dengan asam lemak tak jenuh berguna untuk merubah sifat-sifat aterogenik karena disiplidemia yang ditandai dengan kadar kolesterol HDL yang rendah, trepliserida yang meningkat dan kolesterol LDL meningkat. Penelitian menunjukkan bahwa makanan kaya asam lemak tak jenuh omega-3, khususnya EPA dan Docosa Hexaaonoat Acid (DHA), dapat memperbaiki profil lipoprotein darah. Asam lemak

MEDIKORA Vol. V, No 1, April 2009: 34-54 
omega-3 yang lain yaitu asam linoleat dapat menurunkan risiko infark imokard dan penyakit jantung iskemik pada usinta. Makanan sumber asam lemak omega 3 antara lain adalah ikan terutamá ikan berlemak dari laut seperti ikan tongkol, sarden, salem dan minyak tumbuh-tumbuhan seperti kedelai, jagung, kacang. Dianjurkan untuk mengkonsumsi ikan minimal 2 porsi / mg (50 gr / porsi).

Selain itu, untuk menurunkan dan mempertahankan kadar kolesterol dan lipoprotein dalam darah, dianjurkan untuk mengurangi konsumsi makanan yang kaya akan kandungan asam lemak jenuh dan kolesterol tinggi, 'serta memperbanyak konsumsi sayuran, ikan, polong-polongan dan kacang-kacangan sebagai sumber asam lemak tak jenuh.

\section{PERTAHANKAN TEKANAN DARAH NORMAL}

Asupan garam (Natrium Chlorida) dapat meningkatkan tekanan darah. Beberapa penelitian menunjukkan bahwa rata-rata penurunan asupan natrium $+1,8$ gram/hari dapat menurunkan tekanan darah sistolik $4 \mathrm{mmHg}$ dan diastolik $2 \mathrm{mmHg}$ pada penderita hipertensi dan penurunan lebih sedikit pada individu dengan tekanan darah normal. Respons perubahan asupan garam terhadap tekanan darah bervariasi diantara individu yang dipengaruhi oleh faktor genetik dan juga faktor usia. Disarankan asupan garam < 6 gram sehari atau kurang dari 1 sendok teh penuh. Dari berbagai penelitian, terbukti bahwa kenaikan berat 
badan dapat meningkatkan tekanan darah dan terjadinya hipertensi, walaupun pada program penurunan berat badan. Penurunan tekanan darah dapat terjadi sebelum tercapai berat badan yang diinginkan. Penurunan sistolik dan diastolik rata-rata per $\mathrm{kg}$ penurunan berat badan adalah 1,6/1,1 $\mathrm{mmHg}$. Sehingga dianjurkan untuk selalu menjaga berat badan normal, untuk menghindari terjadinya hipertensi. Dianjurkan untuk tidak mengkonsumsi alkohol atau bahan makanan yang mengandung alkohol karena dapat meningkatkan tekanan darah. Disamping itu alkohol juga dapat menyebabkan kecanduan (Vita Health, 2006).

Dari penelitian-penelitian klinis memperlihatkan pemberian suplemen kalium dapat menurunkan tekanan darah. Dengan suplementasi diet kalium 60-120 mmol/hari dapat menurunkan tekanan darah sistolik dan diastolik 4,4 dan 2,5 $\mathrm{mmHg}$ pada penderita hipertensi dan 1,8 serta $1,0 \mathrm{mmHg}$ pada orang normal. Diet kaya kalium juga dihubungkan dengan penurunan risiko stroke. Asupan diet kalium, Mg dan kalsium sebaiknya bersumber pada bahan makanan alami. Pemberian suplemen harus dikonsultasikan ke dokter terlebih dahulu.

Contoh menu seimbang untuk mencegah hipertensi pada seorang wanita dengan

umur 55 tahun, $\mathrm{BB}=60 \mathrm{~kg}, \mathrm{~TB}=150 \mathrm{~cm}$, Tekanan darah $=$ $130 / 90 \mathrm{mHg}$ dan aktivitas ringan :

IMT $=$ $=26,67$ (kegemukan)

$1,5 \times 1,5$

MEDI KORA Vol. V, No 1, April 2009: 34-54 
BB ideal $=(150-100)-10 \% x \cdot(150-100)=45 \mathrm{~kg}$

Penurunan BB menjadi $50 \mathrm{~kg}$ masih dalam batas $>10 \%$.

Jadi kebutuhan energi dari wanita tersebut diatas adalah :

$\operatorname{BMk}=(8,7 \times 50)+829=522+829=1264$

$\mathrm{AKG}=1,55 \times 1264=1849,25 \mathrm{Kkal}$.

Karena kegemukan, sehingga total kalori diturunkan menjadi $1500 \mathrm{Kkal}$

Kebutuhan karbohidrat : $65 \%$ x $1500=900 \mathrm{kkal}=225$ gram (60-65\%)

Kebutuhan protein : $20 \% \times 1500=300 \mathrm{kkal}=60$ gram $(15-25 \%)$

Kebutuhan lemak : $15 \%$ x $1500=225 \mathrm{kkal}=25$ gram $(10-15 \%)$

\section{KESIMPULAN}

Setiap orang memerlukan jumlah makanan (zat gizi) berbedabeda, bergantung kepada : usia, berat badan, jenis kelamin, aktivitas fisik, kondisi lingkungan (misalnya: suhu), keadaan tetentu ( misalnya: keadaan sakit seperti diabetes, hipertensi, asam urat, dll, ibu hamil atau menyusui). Seorang olahragawan pada umumnya memerlukan makanan lebih banyak dari orang pada umumnya, seorang anak dalam masa pertumbuhan memerlukan protein lebih banyak dibanding orang dewasa. Proporsi makanan sehat berimbang terdiri atas: $60 \%$ karbohidrat, $25 \%$ lemak dan 15 $\%$ protein dari total kebutuhan atau keluaran energi perhari.

Faktor gizi yang sangat berhubungan dengan terjadinya hipertensi melalui beberapa mekanisme. Aterosklerosis merupakan 
penyebàb utama terjadinya hipertensi yang berhubungan dengan diet seseorang, walaupun faktor usia juga berperan, karena pada usia lanjut (usila) pembuluh darah cenderung menjadi kaku dan elastisitashya berkurang. Pembuluh yang mengalami sklerosis (aterosklerosis), resistensi dinding pembuluh darah tersebut akan meningkat. Pembatasan konsumsi lemak sebaiknya dimulai sejak dini sebelum hipertensi muncul, terutama pada orang-orang yang mempunyai riwayat keturunan hipertensi dan pada orang menjelang usia lanjut

\section{Daftar Pustaka}

(2008), Hipertensi dan penyebabnya. Diambil pada tanggal 12 Januari 2009 dari (http://www.pikiran-rakyat.com).

Biokimia Nutrisi dan Metabolisme dengan Pemakaian Secara Klinis, Maria C. Linder, Ph.D, Department of Chemistry, Fullertor, diterjemahkan oleh Aminudin Parakkasi; Penerbit UI Press, 1992

Djoko Pekik Irianto, (2006), Panduan Gizi Lengkap Keluarga dan Olahragawan. Yogyakarta: Andi Offset

Depkes RI (1995) Panduan 13 Pesán Dasar Gizi Seimbang, Jakarta: Depkes RI

Pedoman Makan Untuk Kesehatan Jantung Indonesia, PERKI Pusat dan Yayasan Jantung Indonesia; Jakarta, 2002

Penuntun Diet, Bagian Gizi RSCM dan PERSAGI; Jakarta, 1996

MEDIKORA Vol. V, No 1, April 2009: 34-54 
Vitahealth. (2006). Hipertensi, Jakarta: PT Gramedia Pustaka Utama. 